\title{
IНТЕНСИВНІСТЬ РОСТУ ТА ОПЛАТА КОРМУ САМЦІВ СВИНЕЙ ЗА РІЗНОГО СПОСОБУ КАСТРАЦІї
}

Повод Микола Григорович

доктор с.-г. наук, профессор

Сумський національний аграрний університет ORCID: 0000-0001-9272-9672/ W-1565-2018

E-mail: nic.pov@ukr.net

Шпетний Микола Борисович кандидат с-.-г. наук, ст. викладач Сумський національний аграрний університет ORCID: https://orcid.org/0000-0003-4757-5875/ W-3978-2018

E-mail: nshpetny@gmail.com

Михалко Олександр Григорович аспірант спец. 204 - ТВППТ

Сумський національний аграрний університет ORCID: 0000-0002-0736-2296/ G-2305-2018

E-mail: snau.cz@ukr.net

Жижка Станіслав Васильович аспірант спец. 204 ТВППТ

Сумський національний аграрний університет ORCID: https://orcid.org/0000-0001-9645-8013

E-mail: dust.delacrua@gmail.com

Пелипенко Анастасія Вікторівна аспірант спец. 204 ТВППТ

Сумський національний аграрний університет ORCID: 0000-0001-6579-2254/ AAH-2088-2019

E-mail: pelipenko2011@meta.ua

Михайлик Вікторія Олексіївна викладач Маловисторопський коледж Сумського національного аграрного університету ORCID: https://orcid.org/0000-0002-2410-2234 E-mail: viktoriamihajlik777@gmail.com

В роботі вивчено порівняння інтенсивності росту в різні вікові періоди, некастрованих та кастрованих кнурів за допомогою класичної хірургічної та імунологічної кастрації. Встановлено, що некастровані поросята в період дорощування мали кращу конверсію корму при практично рівній інтенсивності росту. Під час відгодівлі найвищу інтенсивність росту до віку 120 діб мали некастровані кнурці, далі імунологічні та хірургічні кастрати. 3 121-ї по 165-ту добу найвищу інтенсивність росту виявили імунологічні кастрати, далі некастровані кнуриі і найменш інтенсивно росли хірургічні кастрати. За весь періоди відгодівлі найбільш інтенсивно росли імунокастровані самці. Під час відгодівлі було виявлено різницю в інтенсивності росту між хірургічними кастратами, імунокастратами та некастрованими кнурами. За період відгодівлі найкраще оплачували корм приростом імуно-кастровані тварини, які витрачали на один кілограм приросту 0,09 на 2,8 \% менше корму порівняно з некастрованими і на 11,4 \% порівняно з хірургічними кастратами. Індекс відгодівельних якостей мав найвище значення у імунологічно кастрованих тварин 126,7 балів, у кнурів він був на 4,2 бали або на 3,3\% менший, а у хірургічних кастратів склав 118,3 бали, що менше чим у імунокастратів на 8,4 бали або на 6,6 \%. Некастровані поросята в період дорощування мали кращу конверсію корму при практично рівній інтенсивності росту. Відносні прирости в різні періоди життя у хірургічних кастратів, імунокастратів та кнурів поперемінно змінювались, та за весь період життя виявились практично рівні. Не встановлено залежності збереженості та інтенсивності росту поросят в підсисний період.

Ключові слова: поросята, годівля, продуктивність, кастрація, прирости, інтенсивність росту, індекс відгодівельних якостей.

DOI: https://doi.org/10.32845/bsnau.lvst.2019.4.4

Для підтримання продовольчої безпеки України од- | ним з найважливіших завдань на сьогоднішній день $є$ збіль- 
шення виробництва м'яса в нашій країні. Для вирішення цієї задачі поряд з покращенням генетичної складової, удосконаленням годівлі та умов утримання свиней існує чимало резервів пов'язаних з більш повним використанням їх фізіологічних можливостей, одним з яких є відгодівля некастрованих кнурців та заміна хірургічної кастрації на більш сучасні методи покращення якості свинини у самців свиней. Також актуальності цій проблемі надає глобальне поширення ідей гуманізму в ставленні до тварин, в тому числі і в аграрному виробництві.

Кастрація, яка широко застосовується в свинарстві багато років для усунення неприємного запаху і смаку м'яса та сала самців свиней полягає в припиненні функцій статевих залоз, що запобігає накопиченню в салі та м'ясі тварин скатолу, та андростенолу - речовин, які спричиняють неприємний його смак та запах [2]. Але ця процедура спричиняє збільшення жировідкладення, стримує розвиток м'язової тканини, погіршує конверсію корму, так як тваринний організм на утворення жиру витрачає значно більше поживних речовин корму ніж на формування м'язової тканини [3].

3а свідченнями багатьох дослідників $[2,7,8,10,15]$ кастровані кнурці стають флегматичними, спокійними, у них знижуються окислювальні процеси в організмі і як результат вони стають схильними до ожиріння. Тобто кастрація, це штучно створена патологія організму, яка сприяє відкладенню жиру взамін розвитку м'язової тканини. Таким чином кастрація кнурів погіршує якість туші тварини, знижує ії інтенсивність росту та погіршує оплату корму. $[2,9,10,18]$. До цього долучаються питання підвищення добробуту тварин задекларовані в директиві ЄС 2008/120/ЕС від 18/12/2008p [14] та глобальний тренд на добру практику в свинарстві.

Дослідження продуктивності кнурів та боровків проводилось в продовж останніх 50 років, як в нашій країні так і за кордоном. Питання кастрації безпосередньо пов'язано з економікою свинарства так як впливає на інтенсивність росту свиней, якість їх туш та якість м'яса. Як стверджують А. Мікяленас, А. Тарвайніс [4] не кастровані кнури мали вищу енергію росту в порівнянні з боровками, в них були довші на 2,4 см туші та на 10,8 мм менша товщина шпику над 6-7 грудним хребцем та на 9,1 \% більший вихід м'яса.

Таким чином відгодівля кнурів $є$ економічно доцільною завдяки покращенню конверсії корму, підвищенню інтенсивності їх росту та збільшенню виходу м'яса $[4,8]$. Тому відгодівля некастрованих кнурів для виробництва свинини впродовж багатьох років використовується в низці країн Європи таких як Великобританія, Іспанія, Португалія, Ірландія. Поступово відгодівлю некастрованих кнурів впроваджують в Німеччині, Франції, Нідерландах та Бельгії [19] Відгодівля кнурів поряд з перевагами має і свої недоліки. Вона потребує збалансованої годівлі тому, що до настання статевої зрілості кнурів необхідно досягти високої їх живої маси та організації відповідного утримання з урахуванням підвищеної їх агресивності [19]. В зв'язку з чим особливу увагу привертає процедура кастрації кнурців, від ефективного виконання якої залежить якість м'яса і сала та композиція туш, від якої в свою чергу залежить ціна на них [16] і відповідно економіка галузі.

Не зважаючи на переваги при відгодівлі кнурів головною перешкодою до її впровадження та відходу від застосування хірургічної кастрації залишається наявність неприємного специфічного присмаку в тушах від некастрованих тварин. У тварин сучасних генотипів, які забиваються до настання статевої зрілості, прояв специфічного присмаку кнура не $є$ дуже відчутний, але погіршує якість свинини і особливо сала.

Тому в Україні як правило продовжується використання хірургічної кастрації кнурів для їх відгодівлі. Цей метод кастрації у свинарстві практикується дуже давно і використовується для запобігання специфічного запаху кнура, який розвивається в м'ясі статевозрілих некастрованих кнурів та зменшення агресії в їх поведінці $[2,4,6,9]$. Але незважаючи на сталу традицію використання хірургічної кастрації зараз в світі цей процес почав розглядатись частиною людства як стресове явище з негативними наслідками для благополуччя тварин. Тому враховуючи світові тенденції, та прагнення експорту української свинини в країни ЄС дане питання потребує спеціального дослідження.

Серед багатьох можливих варіантів відгодівлі кнурів без застосування хірургічної кастрації можна виділити такі як інтенсивна відгодівля кнурів та їх забій в молодому нестатевозрілому віці [11], застосування спеціальних кормових препаратів для усунення специфічного запаху, селекція тварин [15], штучне зниження активності гіпоталамогіпофрізарно-гонадної осі [13], а також хімічна та імунологічна кастрація [17], з яких найбільш дискусійним є питання імунологічної кастрації [12]

В Україні на законодавчому рівні дозволено застосування імунокастрації та забій імунокастрованих кнурів шляхом внесення змін в чинний ДСТУ 4718: 2007 «Свині для забою. Технічні умови» [5], хоч в нашій державі найближчим часом не очікується законодавчої заборони хірургічної кастрації, актуальним є питання економічної доцільності імунокастрації через зацікавленість цього методу у виробників та його вплив на якісні показники туш.

Матеріали та методи досліджень. Матеріалом для досліджень слугували свині отримані в результаті гібридизації свиноматок $F_{1}$ від ірландського йоркшира та ірландського ландраса, яких осіменили кнурами синтетичної термінальної лінії максгро. Для проведення досліджень на товарному репродукторі № 2 ТОВ «НВП «Глобинський свинокомплекс» в період опоросу свиноматок 10 технологічної групи, яка складала 240 голів в тижневий термін, було відібрано за методом пар-аналогів від 25 свиноматок 3 групи кнурців по 25 голів в кожній. Три нормально розвинених кнурці з кожного гнізда ідентичних за масою, було індивідуально зважено, пронумеровано бирками червоного, голубого та жовтого кольору з індивідуальними номерами. Кнурці першої (контрольної) групи в кількості 25 голів були хірургічно кастровані на четвертий день життя, а кнурців другої та третьої дослідної груп, також в кількості 25 голів в кожній помічені бирками голубого та жовтого кольору, були залишені не кастрованими.

Під час підсисного періоду поросята всіх трьох груп знаходились в одній секції для опоросу в центральному його ряду. Годівля свиноматок у секції проводилась однаковим сухим повнораціонним комбікормом для лактуючих свиноматок на основі преміксу компанії Cargill. Підгодівля поросят всіх трьох груп проводилась однаковим престартерним комбікормом Tupbo 22000 компанії Cargill.

В цей період в усіх трьох групах враховувались вибуття поросят та їх причини, дата вибуття та маса тварин, що вибули. 
Перед відлученням поросята всіх груп були індивідуально зважені на репродукторі з фіксацією їх маси та переведені на дорощування на свинокомплекс з дорощування поросят, де були поставлені в окремі аналогічні станки. Поросята всіх трьох груп утримувались в ідентичних умовах в трьох суміжних станках з частково щілинною підлогою та нормою площі 0,32 м² на кожне порося. Суцільна бетонна підлога (50\% площі станка) обладнана регульованим підігріBOM.

Годівля поросят всіх трьох груп до 41 доби їхнього життя продовжувалась престартерним комбікормом марки Tupbo 22000 з групових самогодівниць. Тип годівлі сухий за допомогою гранульованого комбікорму, годівля свиней проводилась необмежено. 341 по 48 добу було проведено поступове переведення на годівлю сухим розсипчастим комбікормом марки 3802 стартер компанії Cargill.

3 метою обліку корму на час дослідження шибер труби транспорту корму в дослідних станках було закрито і подача корму в самогодівниці здійснювалась за допомогою відер при постійному його зважуванні та фріксації витрат корму. Також постійно контролювалась наявність корму в самогодівницях у тварин всіх піддослідних груп та ступінь регулювання самогодівниці. В цей період також враховувались ветеринарні заходи в кожній групі поросят, дата вибуття, їх причини та маса тварин, які вибули.

370 дня життя тварин всіх груп поступово переведено на комбікорм першої фази відгодівлі рецепту гровер 3060 , який вироблено на власному комбікормовому заводі на основі преміксу компанії Cargill. По закінченню періоду дорощування на 77 день життя підсвинків всіх трьох груп було індивідуально зважено і переведено в цех відгодівлі. На відгодівлі поросят утримували в контрольних станках по 20 голів на повністю решітчастій підлозі з розрахунку 0,7 м² на одну голову. Годівля свиней здійснювалась рідкими кормосумішами на основі комбікорму гровер 30-60 власного виробництва на основі преміксу компанії Cargill за допомогою системи рідкої годівлі WEDA. Облік кормів в кожній групі здійснювався автоматично на комп'ютері системою годівлі і додатково щоденно фіксувався в акті обліку кормів. Під час всього періоду годівлі враховувались ветеринарні заходи, вибуття поросят та їх причини, дата вибуття та маса тварин, що вибули.

На сьомий день після переведення в цех відгодівлі підсвинків другої дослідної групи було провакциновано вакциною Improvac фірми Zoetis з розрахунку 2 мл на голову. На 125 добу життя було проведено ревакцинацію тварин другої дослідної групи за такою ж схемою.

На 120 добу життя при переведенні на комбікорм гровер 60-90, поросята всіх трьох груп були індивідуально зважені.

По досягненні середньої маси 90 кг по трьох групах їх було переведено на годівлю комбікормом фінішер 90-110. За середньої маси 100 кілограм у трьох групах всі піддослідні свині були індивідуально зважені.

За результатами відгодівлі було розраховано індекс відгодівельних якостей за формулою М.Д. Березовського [ 1 ]:

$$
I=\frac{A^{2}}{B * C}
$$

де: А - валовий приріст за період відгодівлі, кг;

В - кількість діб відгодівлі;

C - витрати корму на 1 кг приросту, корм. од.

Результати досліджень. За результатами дослідження (табл. 1) встановлено, що в контрольній групі за час підсисного періоду вибуло 3 голови поросят, в II дослідній групі вибуло за цей час 1 порося, а в III дослідній - 3 голови.

Таблиця 1

Інтенсивність росту та збереженість кнурців та хірургічних кастратів в підсисний період

\begin{tabular}{|l|c|c|c|}
\hline \multicolumn{1}{|c|}{ Показник } & $\begin{array}{c}\text { І група (контрольна) } \\
\text { хірургічні кастрати }\end{array}$ & $\begin{array}{c}\text { II група (дослідна) } \\
\text { некастровані кнурці }\end{array}$ & $\begin{array}{c}\text { III група (дослідна) } \\
\text { некастровані кнурці }\end{array}$ \\
\hline Кількість поросят при постановці на дослід, гол & 25 & 25 & 25 \\
\hline Маса поросят при постановці на дослід, кг & 31,1 & 31,0 & 30,8 \\
\hline Маса 1 поросяти, кг & $1,24+0,07$ & $1,24+0,0,7$ & $1,23+0,08$ \\
\hline Кількість поросят при відлученні, гол & 22 & 24 & 22 \\
\hline Маса поросят при відлученні, кг & 169,2 & 190,6 & 170,1 \\
\hline Маса 1 голови при відлученні, кг & $7,69+0,10$ & $7,94+0,09$ & $7,73+0,11$ \\
\hline Падіж в підсисний період, гол & 3 & 1 & 3 \\
\hline Відсоток вибуття, \% & 12,0 & 4,0 & 12,0 \\
\hline Збереженість, \% & 88 & 96 & 88 \\
\hline Середньодобовий приріст в підсисний період, г & 230 & 239 & 232 \\
\hline
\end{tabular}

При постановці на дослід маса поросят на другий день їх життя у всіх трьох групах була практично рівною в межах 1,23-1,24 кг.

До відлучення інтенсивність росту поросят всіх трьох дослідних груп була майже однаковою. Тварини II дослідної групи мали тенденцію до більш швидкого росту і на кінець періоду дорощування мали вищу на 0,25 кг середню масу поросят.
Збереженість у I та III групах склала 88\%, а в II 96\%. Відхід поросят зумовлений асфріксією та їх дистрофрією, що не пов'язано з кастрацією.

Таким чином не виявлено залежності збереженості та інтенсивності росту поросят в підсисний період від процесу їх кастрації. (табл.2)

За період дорощування вибула одна голова у II групі 
Таблиця 2

Продуктивність кнурців та хірургічних кастратів в період дорощування

\begin{tabular}{|c|c|c|c|}
\hline Показник & $\begin{array}{c}\text { I група (контрольна) } \\
\text { хірургічні кастрати }\end{array}$ & $\begin{array}{c}\text { II група (дослідна) } \\
\text { некастровані кнурці }\end{array}$ & $\begin{array}{c}\text { III група (дослідна) } \\
\text { некастровані кнурці }\end{array}$ \\
\hline Кількість поросят при постановці на дорощування, гол & 22 & 24 & 22 \\
\hline Маса поросят при постановці на дорощування, кг & 169,2 & 190,6 & 170,1 \\
\hline Мaca 1 поросяти, кг & 7,69 & 7,94 & 7,73 \\
\hline Вибуло поросят під час дорощування, гол & 0 & 1 & 0 \\
\hline Маса поросят що вибули, кг & & 14,3 & \\
\hline Кількість поросят по завершенню дорощування, гол & 22 & 23 & 22 \\
\hline Відсоток вибуття, \% & & 4,2 & \\
\hline Маса поросят по завершенню дорощування, кг & 673,2 & 713,9 & 677,6 \\
\hline Маса 1 голови по завершенню дорощування, кг & $30,60+0,17$ & $31,04+0,18$ & $30,8+0,21$ \\
\hline Збереженість, \% & 100 & 95,8 & 100 \\
\hline Абсолютний приріст живих поросят за час дорощування, кг & 504,0 & 523,3 & 507,5 \\
\hline Абсолютний приріст поросят з врахуванням маси тих що вибули, кг & 504,0 & 537,6 & 507,5 \\
\hline Витрачено корму всього, кг & 952,6 & 973,1 & 928,7 \\
\hline Конверсія корму, кг & 1,89 & 1,81 & 1,83 \\
\hline Конверсія корму, корм. од. & 2,14 & 2,06 & 2,07 \\
\hline
\end{tabular}

Примітки: ${ }^{* *}(p<0,001) ;{ }^{* *}(p<0,01) ;{ }^{*}(p<0,05) ;$

По закінченню періоду дорощування поросята всіх трьох груп були індивідуально зважені. Жива маса тварин першої групи склала - 637,2 кг, другої 713,9 кг та третьої 677,6 кг. Індивідуальна маса поросят виявилась найвищою у тварин II дослідної групи, які не вірогідно на 1,4\% переважали тварин I контрольної групи, тоді як перевага тварин II ї групи склала всього 0,7\%.

За період дорощування поросята I контрольної групи витрачали 1,89 кг, або 2,14 корм. од. корму на кілограм приросту, тоді як їх аналоги з II групи мали на 4,4\%, а твари- ни III групи на 3,3\% кращу конверсію корму відповідно

Таким чином некастровані поросята II та III груп мали дещо кращу конверсію корму при практично рівній інтенсивності росту.

Під час відгодівлі з'явилась різниця в інтенсивності росту між хірургічними кастратами, імунокастратами та некастрованими кнурами. Як витікає 3 табл. 3 та рис 1-3 під час відгодівлі свині піддослідних груп мали не однакову інтенсивність росту.

Динаміка росту свиней за різного способу кастрації ( $\mathrm{n}=20$ )

Таблиця 3

\begin{tabular}{|c|c|c|c|c|c|}
\hline \multirow{2}{*}{ Група } & \multicolumn{5}{|c|}{ Маса свиней кг, в вікові періоди, діб } \\
\cline { 2 - 6 } & при народженні & $\mathbf{2 8}$ діб & $\mathbf{7 7}$ діб & $\mathbf{1 2 0}$ діб & 165 діб \\
\hline I & $1,24 \pm 0,07$ & $7,69 \pm 0,10$ & $30,60 \pm 0,17$ & $60,17 \pm 0,523$ & $99,24 \pm 0,717$ \\
\hline II & $1,24 \pm 0,07$ & $7,94 \pm 0,09$ & $31,04 \pm 0,18$ & $65,54 \pm 0,562^{* * *}$ & $105,98 \pm 0,674^{* * *}$ \\
\hline III & $1,23 \pm 0,08$ & $7,73 \pm 0,11$ & $30,80 \pm 0,21$ & $66,22 \pm 0,612^{* * *}$ & $103,54 \pm 0,754^{* *}$ \\
\hline \multicolumn{7}{|c|}{ Примітки: ${ }^{* *}(p<0,001) ;{ }^{* *}(p<0,01) ;$}
\end{tabular}

Так під час зважування у віці 120 діб тварини I контрольної групи мали середню масу однієї голови 60,17 кг, в той час як їх аналоги з II дослідної групи були на 5,25 кг або $8,7 \%$ важчими (p<0,001). Переваги некастрованих кнурців (III група) над хірургічними кастратами склала 6,03 кг або 10,0\% $(p<0,001)$.

В наступні 45 діб найбільш інтенсивно росли імунокастровані тварини (II група), які переважали хірургічно кастрованих (I група) за масою, в 165 днів, на 6,74 кг або $6,8 \%$ (p<0,001). Не кастровані кнури (III група) в цей період мали дещо нижчу інтенсивність росту і були важчими за тварин контрольної групи на 4,26 кг або 4,3\% (p<0,01). Перевага імунокастратів (II група) над кнурами (III група) склала 2,4 кг, що становить 2,4\% ( $<<0,05)$.

Витрати корму в усіх трьох групах вираховувались по вікових періодах життя тварини з 29 по 77 день період дорощування і два періоди відгодівлі - 78-120 діб, годівля гровером 30-60 та 121-165 діб, годівля фінішером 60-90.

В цілому за період дорощування та відгодівлі піддослідні тварини витрачали на 1 кг приросту 2,31-2,63 кг корму, що в переведенні на кормові одиниці складає 2,71-2,97 (табл 4).

В цей період найкращу конверсію корму продемонстрували імунокастрати (II група), які на 0,15 кг (0,17 корм. од.), або 6,5\%, переважали за цим показником некастрованих кнурів (III група) та на 0,32 кг (0,36 корм. од.), або 13,9\%, хірургічних кастратів (II група).

За період відгодівлі найкраще оплачували корм приростом також імунокастровані тварини (II група), які витрачали на один кілограм приросту на 0,08 кг (0,09 корм. од.), або на 2,8 \% менше корму порівняно з некастрованими (III група) і на 0,33 кг (0,35 корм. од.) або 11,4 \% порівняно 3 хірургічними кастратами (I група). 
Конверсія корму самців свиней за різного способу кастрації

Таблиця 4

\begin{tabular}{|c|c|c|c|c|c|c|c|c|c|c|}
\hline \multirow{3}{*}{ Група } & \multicolumn{10}{|c|}{ Витрати корму за період, діб } \\
\hline & \multicolumn{2}{|c|}{ 29-77 діб } & \multicolumn{2}{|c|}{ 78-120 діб } & \multicolumn{2}{|c|}{ 121-165 діб } & \multicolumn{2}{|c|}{$29-165$} & \multicolumn{2}{|c|}{$78-165$} \\
\hline & Кг & корм. од. & кг & корм. од. & кг & корм.од. & Кг & корм.од. & кг & корм. од \\
\hline 1 & 1,89 & 2,14 & 2,67 & 3,12 & 3,40 & 3,74 & 2,63 & 2,97 & 3,22 & 3,44 \\
\hline II & 1,81 & 2,06 & 2,14 & 2,50 & 3,01 & 3,61 & 2,31 & 2,61 & 2,89 & 3,09 \\
\hline III & 1,83 & 2,07 & 2,47 & 2,89 & 3,13 & 3,44 & 2,46 & 2,78 & 2,97 & 3,17 \\
\hline
\end{tabular}

При аналізі абсолютних приростів (рис. 1) видно, що до переведення на відгодівлю різниці між кастрованими та не кастрованими тваринами не встановлено, за перші 43 доби відгодівлі найбільшу прибавку маси 35,45 кг, або 19,9 $\%$, мали некастровані кнурці (III група). Тварини після першої вакцинації вакциною Improvac (II група) приросли дещо менше, їх перевага над контролем (I група) склала 4,93 або $16,7 \%$ відповідно. Не кастровані кнурці (III група) за цей період наростили масу свого тіла на 35,45 кг, або 2,7 \% більше в порівнянні з імунологічними кастратами (II група).

В наступні 45 діб відгодівлі найменшим приростом маси тіла відрізнялись кнурці (III група). Вони мали абсолютний приріст на 1,75 кг менше в порівнянні 3 хірургічними кастратами (І група), на 3,12 кг в порівнянні з імунокастратами (II група). В той час як останні переважали хірургічних кастратів на 1,37 кг, або 3,5 \%.

В цілому за період життя найбільше маси тіла наростили імунокастрати (II група) 104,74 кг. Не кастровані кнурці (III група) мали цей показник на 2,43 кг або 2,4 \% меншим, в той час як хірургічних кастратів (I група) вони переважали на 4,31 кг, або 6,9\%.

За період відгодівлі спостерігалась аналогічна тенденція. Найменше маси тіла наростили хірургічні кастрати (I група) 69 кг, а найбільше імунокастрати (II група) - 74,94 кг, тоді як не кастровані кнурі (III група) зайняли проміжне місце 72,74 кг.

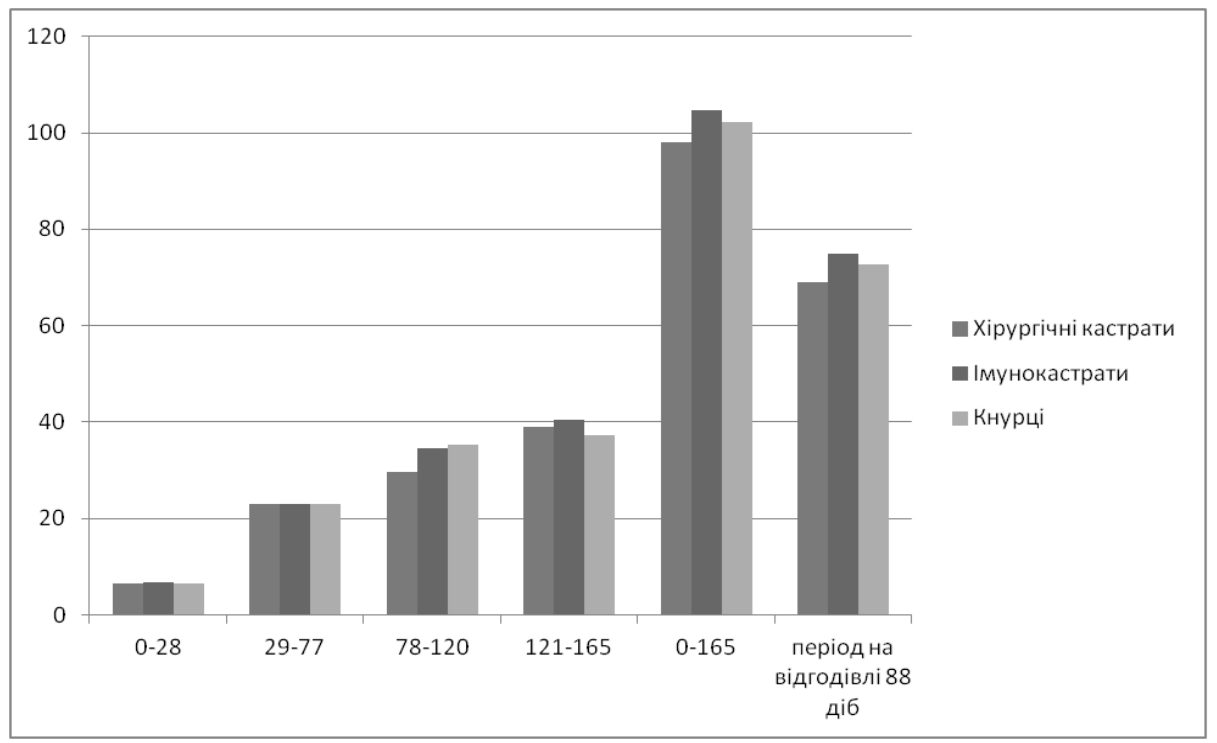

Рис. 1. Динаміка абсолютних приростів кнурців, хірургічних кастратів та імунокастратів

При аналізі середньодобових приростів (рис. 2) встановлено їх практичну рівність в підсисний період та період дорощування. В перші 43 доби відгодівлі найбільш інтенсивно приростали некастровані тварини (III група). На 22 г приросту, або 2,7 \%, їм поступались імунокастрати (II група), та 136 г або16,6 \%, хірургічні кастрати (І група). За наступні 45 діб відгодівлі найбільший середньодобовий приріст мали імунокастрати 899 г , а найменший не кастровані кнури 829 г. Хірургічні кастрати мали середньодобовий приріст 868 г, що на 39 г або на 4,7\%, вище в порівнянні 3 не кастрованими тваринами і на 31 г 3,6 \% нижче імунокастратів

За весь період життя найвищими середньодобовими приростами відрізнялись імунокастрати (II група), які переважали за цим показником хірургічних кастратів (I група) на 40,8 г , або 6,7 \%, та не кастрованих кнурів (III група) на 14,7 г, або $2,4 \%$. 


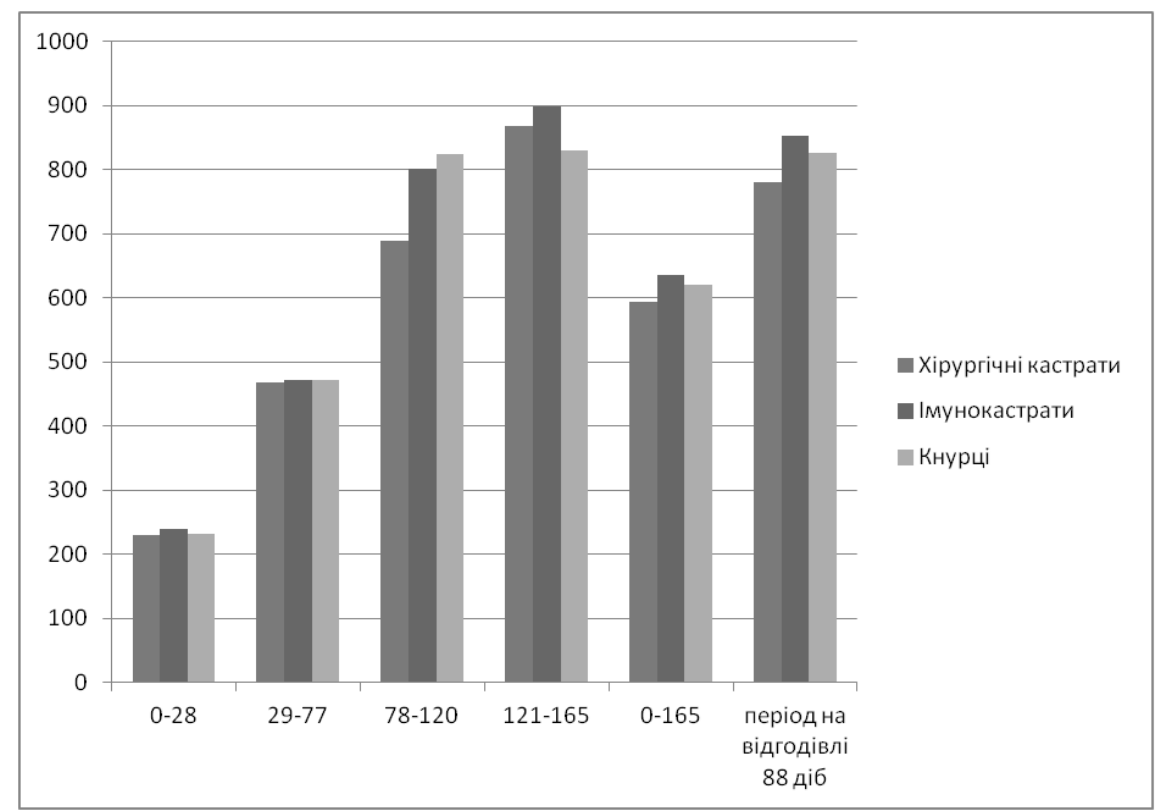

Рис 2. Динаміка середньодобових приростів кнурців, хірургічних кастратів та імунокастратів

За 88 діб відгодівлі найвищими приростами вирізнялись також імунокастровані тварини (II група), які переважали хірургічних кастратів (I група) на 71,6 г або 9,2\% та не кастрованих кнурів (III група) на 25,3 г або 3,1\%. В свою чергу останні мали перевагу над хірургічними кастратами на 46,3 г $5,9 \%$.

Ця ситуація на нашу думку пов'язана з фізіологією тварин. До початку відгодівлі вплив статевого дозрівання не вплинув на інтенсивність росту тварин, в перші 43 доби відгодівлі найвищу інтенсивність росту виявили не кастровані тварини, тому що в природній перебіг фізіологічних процесів не було втручання. На нашу думку, за рахунок, стресу, пов'язаного з введенням вакцини та відповідною реакцією організму на її введення, імунокастрати мали дещо нижчий приріст порівняно з некастрованими кнурами. Хірургічні кастрати мали найнижчу енергію росту через певні зміни в фізіології пов'язані 3 кастрацією та відповідними змінами в гормональному статусі тварин.

В період заключної відгодівлі не кастровані кнури проявляли підвищену активність, агресивність і тому, на наш погляд, знизили інтенсивність росту. Імунокастрати після двох вакцинацій не мали агресивної поведінки, вели себе спокійно і як результат мали найвищу інтенсивність росту. Дещо їм поступались хірургічні кастрати. В цілому як за весь період життя так і за весь період відгодівлі найвищу інтенсивність росту продемонстрували імунологічно кастровані свині.

При аналізі відносних приростів (рис. 3) встановлено їх зниження зі зростанням віку тварин. Найвищі відносні прирости мали тварини всіх піддослідних груп в підсисний період. В розрізі піддослідних груп різниці не встановлено. В період дорощування відносні прирости дещо знизились і за їх величиною особливої різниці також не спостерігалось. В перші 43 доби відгодівлі найвищі відносні прирости мали не кастровані кнури 73,02 \% (III група), імунологічні кастрати (II група) поступались їм на 1,6 \%, та хірургічні кастрати відповідно - на 7,9 \%. 


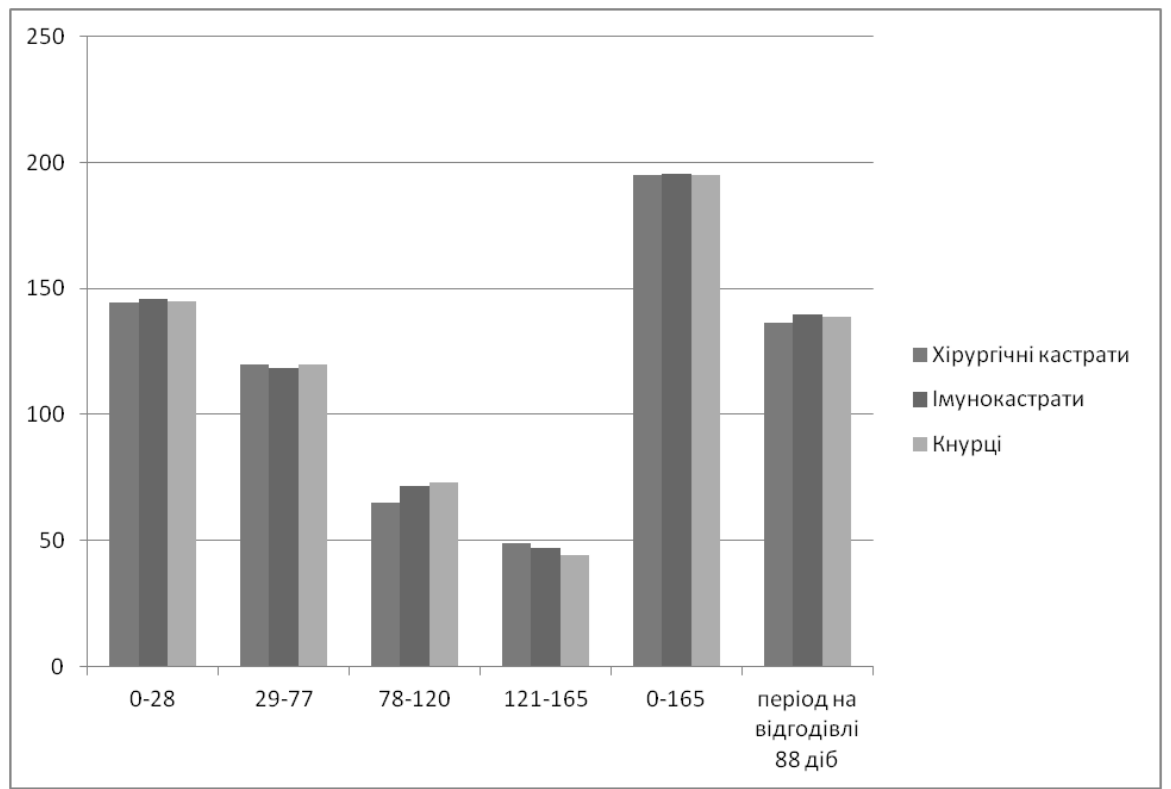

Рис 3. Динаміка відносних приростів кнурців, хірургічних кастратів та імунокастратів

Протилежна тенденція за відносними приростами спостерігалась в заключний період відгодівлі, де найвищі відносні прирости мали хірургічні кастрати, а найнижчі - не кастровані тварини.

За період життя відносні прирости у тварин всіх піддослідних груп були майже рівні, в той час як за період відгодівлі дещо вищим цей показник був у імунокастратів $139,79 \%$, тоді як у кнурів він склав 138,86 \%, а хірургічних кастратів 136,62\%.

Таким чином, відносні прирости за різні періоди життя у хірургічних кастратів, імунокастратів та кнурів поперемінно змінювались, та за весь період життя виявились практично рівні.

За результатами розрахунку індексу відгодівельних якостей за формулою М.Д. Березовського встановлено його найвище значення у імунокастрованих тварин 126,7 балів, тоді як у кнурів цей індекс був на 4,2 бали або на 3,3\% менший, а у хірургічних кастратів склав 118,3 балів, що менше чим у імунокастратів на 8,4 бали або на 6,6 \%

\section{Висновки.}

1. Не встановлено залежності збереженості та інтенсивності росту поросят в підсисний період від процесу їхньої кастрації.
2. Некастровані поросята в період дорощування мали кращу конверсію корму при практично рівній інтенсивності росту.

3. До віку 120 діб найвищу інтенсивність росту мали некастровані кнурці, далі імунокастрати і хірургічні кастрати. За період з 121 по 165 добу найвищу інтенсивність росту виявили імунокастрати, далі некастровані кнурці і найменш інтенсивно росли хірургічні кастрати. За весь періоди відгодівлі найбільш інтенсивно росли імунокастровані самці.

4. Відносні прирости виявились практично рівними за весь період життя, тоді як в різні його періоди вони поперемінно змінювались у хірургічних кастратів, імунокастратів та кнурів.

5. За період відгодівлі найкраще оплачували корм приростом імунокастровані тварини, які витрачали на один кілограм приросту на 2,8 \% менше корму порівняно з некастрованими і на 11,4 \% порівняно з хірургічними кастратами.

6. Індекс відгодівельних якостей мав найвище значення у імунокастрованих тварин - 126,7 балів, у кнурів він був на 4,2 бали або на 3,3\% менший, а у хірургічних кастратів склав 118,3 балів, що менше ніж у імунокастратів на 8,4 бали або на $6,6 \%$

\section{Список використаної літератури:}

1. Березовский Н.Д., Гетя А.А., Ващенко П.А. Селекционная работа с крупной белой породой свиней в Украине. Современные проблемы интенсификации производства свинины: мат. межд. конф. Ульяновск, 2007. Т.1. С. 29-33.

2. Голдобин М.И., Журавлева Л.И, Тобоев Г.М. Откорм. Свиноводство. 1995. № 4. С. 20-22.

3. Ивченко А.Н. Рост, развитие и мясные качества хрячков, боровков и свинок при откорме их на мясо. Автореферат диссертации на соискание ученой степени кандидата сельскохозяйственных наук Белгород, 2006. С.19

4. Микяленас А., Тарвайнис А. Эфффективность выращивания и вкусовая оценка качества мяса и мясных продуктов хрячков, свинок и кастратов. Проблемы создания высокопродуктивных линий и типов свиней. Москва. 1988. С. 53-54. 2014 рік.

5. Національний стандарт України. ДСТУ 4718: 2007 «Свині для забою. Технічні умови». Київ, Мінекономіки України,

6. Повод М., Кравченко О., Гетя А. Вплив різних способів кастрування на забійні та м'ясні якості туш свиней. Прибуткове свинарство. 2017. №11. С.32-34.

7. Повод М.Г., Кравченко О.І., Гетя А.А., Самохіна Є.А., Шпетний М.Б. Інтенсивність росту хірургічно кастрованих та не кастрованих гібридних поросят в умовах промислового виробництва свинини. Вісник Сумського національного аграрного університету. Серія «Твариництво». 2017. Вип. 7 (33). С.151-154 
8. Походня Г.С., Мочаловский А.Н. Зависимость прироста живой массы хрячков от методов кастрации. Информационный листок. №50. Белгород. 1986. С.4

9. Стоиков А. и др. Качество мяса откормочных хрячков, боровков и свинок. Животноводческие науки НРБ. 1987. № 2. C. $35-40$.

10. Филатов А. Откормочные и мясные качества хрячков и свинок на контрольном выращивании. А. Филатов, JI. Симолкин, и др. Свиноводство. №4. 2003. С. 17.

11. American veterinary medical association. Literature Review on the Welfare Implications of Swine Castration. May 29.

12. Andersson K, Brunius C, Zamaratskaia G, Lundström K. Early vaccination with Improvac: effects on performance and behaviour of male pigs. Anim 2011. FirstView: pp.1-9.

13. Daxenberger A, Hageleit M, Kraetzl W, Lange I, Claus R, Bizec B and Meyer H 2001 Suppression of androstenone in entire male pigs by anabolic preparations. Livestock Production Science 69: pp. 139-144.

14. European Union. Council Directive 2008/120/EC of 18 December 2008 laying down minimum standards for the protection of pigs. OJ L 47, 18.2.2009.

15. Frieden L., Looft C. and Tholen E. Breeding for reduced boar taint. Lohman Information 2011, Vol.46(1): pp. 21-27.

16. Moorea K.L., Mullanc B.P., Dunsheaa F.R. Boar taint, meat quality and fail rate in entire male pigs and male pigs immunized against gonadotrophin releasing factor as related to body weight and feeding regime. Meat Science. Volume 125, March 2017, pp. 95-101.

17. Prunier A., Bonneau M., von Borell EH, Cinotti S., Gunn M., Fredriksen B., Giersing M., Morton DB., Tuyttens FAM and Velarde A. A review of the welfare consequences of surgical castration in piglets and the evaluation of non-surgical methods. Anim Welf. 2006;15: pp. 277-89

18. The effects of gender and slaughter weight on the growth performance, carcass traits, and meat quality characteristics of heavy pigs / M. A. Latorre [et al.]. Journal of Animal Science. 2004. Vol. 82. pp. 526-533.

19. Wesoly R, Jungbluth I, Stefanski V, Weiler U. Pre-slaughter conditions influence skatole and androstenone in adipose tissue of boars. . - Meat Science Volume 99, January 2015, pp. 60-67.

\section{References:}

1. Berezovskiy, N.D., Getya, A.A. and Vaschenko, P.A., 2007. Selektsionnaya rabota s krupnoy beloy porodoy sviney v Ukraine [Breeding work with a large white breed of pigs in Ukraine] Sovremennyie problemyi intensifikatsii proizvodstva svininyi: mat. mezhd. konf. Ulyanovsk, v.1, pp. 29-33.

2. Goldobin, M.I., L.I. and Toboev, G.M., 1995. Otkorm hryachkov [Fattening boars] Svinovodstvo, issue 4, pp. 20-22

3. Ivchenko, A.N., 2006. Rost, razvitie i myasnyie kachestva hryachkov, borovkov i svinok pri otkorme ih na myaso [Growth, development and meat qualities of boars, hogs and pigs when fattening them for meat] Avtoreferat dissertatsii na soiskanie uchenoy stepeni kandidata selskohozyaystvennyih nauk Belgorod. p. 19

4. Mikyalenas, A. and Tarvaynis, A., 1988. Effektivnost vyiraschivaniya i vkusovaya otsenka kachestva myasa i myasnyih produktov hryachkov, svinok i kastratov [The effectiveness of cultivation and taste assessment of the quality of meat and meat products of boars, gilts and castrates]. Problemyi sozdaniya vyisokoproduktivnyih liniy i tipov sviney. Moskva. pp. 53-54.

5. Minekonomiky Ukrainy, 2014. Svyni dlia zaboiu. Tekhnichni umovy. [Pigs for slaughter. Specifications] Natsionalnyi standart Ukrainy DSTU 4718: 2007. Kyiv.

6. Povod, M., Kravchenko, O. and Hetia, A., 2017. Vplyv riznykh sposobiv kastruvannia na zabiini ta miasni yakosti tush svynei [Influence of different casting methods on slaughter and meat quality of pig carcasses]. Prybutkove svynarstvo, zhovten, issue 11, pp.32-34.

7. Povod M., Kravchenko O., Hetia A., Samokhina Y. and Shpetnyi M. 2017 Intensyvnist rostu khirurhichno kastrovanykh ta ne kastrovanykh hibrydnykh porosiat $v$ umovakh promyslovoho vyrobnytstva svynyny [Growth rate of surgically castrated and noncastrated hybrid pigs in industrial pork production] Visnyk Sumskoho natsionalnoho ahrarnoho universytetu Seriia «Tvarynytstvo», issue 7 (33), pp.151-154

8. Pohodnya G.S. and Mochalovskiy A.N. 1986 Zavisimost prirosta zhivoy massyi hryachkov ot metodov kastratsii [Dependence of the gain in live weight of boars on castration methods] Informatsionnyiy listok \#50. Belgorod. p. 4

9. Stoikov A. 1987 Kachestvo myasa otkormochnyih hryachkov, borovkov i svinok. [The quality of meat of fattening boars, hogs and pigs] Zhivotnovodcheskie nauki NRB. issue 2. pp. 35-40

10. Filatov A., and Simolkin L. 2003 Otkormochnyie i myasnyie kachestva hryachkov i svinok na kontrolnom vyiraschivanii [Feeding and meat qualities of boars and pigs in control cultivation.] Svinovodstvo. issue 4. - p. 17

11. American veterinary medical association. 2013 Literature Review on the Welfare Implications of Swine Castration. May 29., p.5

12. Andersson K, Brunius C, Zamaratskaia G and Lundström K. 2011 Early vaccination with Improvac: effects on performance and behaviour of male pigs. Anim 2011;FirstView: pp.1-9

13. Daxenberger A, Hageleit M, Kraetzl W, Lange I, Claus R, Bizec B and Meyer H 2001 Suppression of androstenone in entire male pigs by anabolic preparations. Livestock Production Science 69: pp. 139-144

14. European Union. Council Directive 2008/120/EC of 18 December 2008 laying down minimum standards for the protection of pigs. OJ L 47, 18.2.2009

15. Frieden L., Looft C. and Tholen E. 2011 Breeding for reduced boar taint. Lohman Information 2011, Vol.46(1): pp.21-27

16. Moorea K.L., Mullanc B.P., Dunsheaa and F.R. 2017 Boar taint, meat quality and fail rate in entire male pigs and male 
pigs immunized against gonadotrophin releasing factor as related to body weight and feeding regime. Meat Science. Volume 125, March 2017, pp. 95-101

17. Prunier A., Bonneau M., von Borell EH, Cinotti S., Gunn M., Fredriksen B., Giersing M., Morton DB., Tuyttens FAM and Velarde A. 2006 A review of the welfare consequences of surgical castration in piglets and the evaluation of non-surgical methods. Anim Welf. 2006;15: pp. 89-277

18. Latorre M. A. 2004 The effects of gender and slaughter weight on the growth performance, carcass traits, and meat quality characteristics of heavy pigs Journal ofAnimal Science. 2004. Vol. 82. pp. 526-533

19. Wesoly R, Jungbluth I, Stefanski V and Weiler U (2015) Pre-slaughter conditions influence skatole and androstenone in adipose tissue of boars Meat Science Volume 99, January 2015, pp. 60-67

\section{Povod, M.G.,}

Shpetniy, M.B.,

Mykhalko, O.G.,

Zhizhka, S.V.,

Pelypenko, A.M.,

Mikhailik, V.O.

Intensity of growth and payment of feed of pigs for different methods of castration

The paper compares the intensity of growth in different age periods, uncastrated and castrated boars with the help of classical surgical and immunological castration. It was found that non-cast pigs had a better feed conversion during the growing-up period with almost equal growth rate. During fattening, the highest intensity of growth until the age of 120 days had uncut casts, and then immunological and surgical castrates. From the 121st to the 165th day, the highest intensity of growth was detected by immunological castrates, further unconstrained sockets and the least intensively growing surgical castrates. During the whole feeding period, immunocastrated males grew most intensively. During the fattening, a difference in growth rate was detected between surgical castrates, immunocastrates, and non-castrated boars. During the fattening period, the feed was best paid for the gain. Immunocastrated animals that consumed $0.09 \mathrm{~kg}$ less $2.8 \mathrm{~kg}$ less feed compared to non-cast animals and $11.4 \%$ compared to surgical castrates. The quality index had the highest value in immunologically castrated animals 126.7 points, in boars it was 4.2 points or $3.3 \%$ lower, and in surgical castrates was 118.3 points, which is less than in immuno castrates by 8,4 points or $6.6 \%$. Non-castrated piglets during the growing season had better feed conversion with almost equal growth rate. The relative increments in different periods of life in surgical castrates, immunocastrates and boils varied, and were virtually equal throughout the life span. There are no dependence of preservation and growth rate of piglets in the feeding period has been established.

Key words: pigs, feeding, productivity, castration, growth, growth rate, fattening index.

Дата надходження до редакції: 12.10.2019 р. 